\title{
Transactions
}

Cite this: Dalton Trans., 2012, 41, 4045

wWw.rsc.org/dalton

PAPER

\section{Multifunctional lanthanum tetraphosphonates: Flexible, ultramicroporous and proton-conducting hybrid frameworks $\uparrow$}

\author{
Rosario M. P. Colodrero, ${ }^{a}$ Pascual Olivera-Pastor, ${ }^{a}$ Enrique R. Losilla, ${ }^{a}$ Miguel A. G. Aranda,${ }^{a}$ \\ Laura Leon-Reina, ${ }^{b}$ Maria Papadaki, ${ }^{c}$ Alistair C. McKinlay, ${ }^{d}$ Russell E. Morris, ${ }^{d}$ Konstantinos D. Demadis $^{* c}$ \\ and Aurelio Cabeza*a
}

Received 20th October 2011, Accepted 13th December 2011

DOI: $10.1039 / \mathrm{c} 2 \mathrm{dt11992g}$

A new flexible ultramicroporous solid, $\mathrm{La}\left(\mathrm{H}_{5} \mathrm{DTMP}\right) \cdot 7 \mathrm{H}_{2} \mathrm{O}(\mathbf{1})$, has been crystallized at room temperature using the tetraphosphonic acid $\mathrm{H}_{8}$ DTMP, hexamethylenediamine- $N, N, N^{\prime}, N^{\prime}$-tetrakis (methylenephosphonic acid). Its crystal structure, solved by synchrotron powder X-ray diffraction, is characterised by a 3D pillared open-framework containing 1D channels filled with water. Upon dehydration, a new related crystalline phase, $\mathrm{La}\left(\mathrm{H}_{5} \mathrm{DTMP}\right)(\mathbf{2})$ is formed. Partial rehydration of $\mathbf{2}$ led to $\mathrm{La}\left(\mathrm{H}_{5} \mathrm{DTMP}\right) \cdot 2 \mathrm{H}_{2} \mathrm{O}(\mathbf{3})$. These new phases contain highly corrugated layers showing different degrees of conformational flexibility of the long organic chain. The combination of the structural study and the gas adsorption characterization $\left(\mathrm{N}_{2}\right.$ and $\left.\mathrm{CO}_{2}\right)$ suggests an ultramicroporous flexible framework. NO isotherms are indicative of a strong irreversible adsorption of NO within the pores. Impedance data indicates that $\mathbf{1}$ is a proton-conductor with a conductivity of $8 \times 10^{-3} \mathrm{~S} \mathrm{~cm}^{-1}$ at $297 \mathrm{~K}$ and $98 \%$ of relative humidity, and an activation energy of $0.25 \mathrm{eV}$.

\section{Introduction}

Lanthanide Metal-Organic Frameworks (Ln-MOFs) are receiving growing interest owing to their potential applications in fields such as photoluminescence, magnetism, catalysis and gas adsorption/sensing. ${ }^{1}$ The rare-earth ions possess rich coordination chemistry, functionality and, additionally, their properties may be modulated across the lanthanide series, which is key for designing advanced multifunctional solid state compounds. Compared to d-block transition metal-containing MOFs, ${ }^{2} \mathrm{Ln}$ MOFs have been relatively much less studied. Porous frameworks are rather scarce, because they usually present less

${ }^{a}$ Departamento de Química Inorgánica, Universidad de Málaga, Campus Teatinos s/n, Málaga, 29071, Spain.E-mail: aurelio@uma.es; Tel: $+34952131870+34952131877$

${ }^{b}$ Servicios Centrales de Apoyo a la Investigación, Universidad de Málaga, Campus Teatinos s/n, Málaga, 29071, Spain

${ }^{c}$ Crystal Engineering, Growth and Design Laboratory, Department of Chemistry, University of Crete, Voutes Campus, Crete, GR-71003, Greece.E-mail: demadis@chemistry.uoc.gr; Fax: +30 2810 545001; Tel: + 302810545051

${ }^{d}$ School of Chemistry, University of St Andrews, Purdie Building, St Andrews, UK, KY16 9ST

$\dagger$ Electronic supplementary information (ESI) available: Fig. S1-S3: XRPD Rietveld plots for compounds 1-3; Fig. S4: Comparison of the raw powder patterns for $\mathrm{Ln}\left(\mathrm{H}_{5} \mathrm{DTMP}\right) \cdot 7 \mathrm{H}_{2} \mathrm{O}(\mathrm{Ln}=\mathrm{La}$, Sm); Fig. S5: framework view for 1 showing the 1D channels; Fig. S6: lattice water molecule chain within the channel of 1. Tables S1-S3: Bond lengths and $\mathrm{H}$-bonding distances for compounds $\mathbf{1}-\mathbf{3}$. CCDC reference numbers 810315-810317. For ESI and crystallographic data in CIF or other electronic format see DOI: $10.1039 / \mathrm{c} 2 \mathrm{dt} 11992 \mathrm{~g}$ oriented metal-linker bonds and the bulky lanthanides usually exhibit high coordination numbers, which result in dense solids. ${ }^{3}$

For solid state applications, such as solid sensors, light-emitting materials or proton conductors, two- or three-dimensional network compounds are required. Due to the high affinity of the rare-earth ions for oxygen-containing species, carboxylate-based ligands have been often used as the linkers of preference, yielding robust framework architectures. For example, Harbuzaru et al. ${ }^{1 \mathrm{~d}}$ have prepared 3D microporous Ln-MOFs, by appropriate selection of the carboxylate ligand under hydrothermal conditions. The products combine a set of well-defined properties in the same crystal, including high gas adsorption, anisotropic photoluminescence and magnetic properties.

Multifunctional phosphonate ligands are alternative organic linkers, leading to a variety of thermally and chemically stable Ln-MOFs architectures. ${ }^{4}$ However, exercising control of the dimensionality and crystal structure of phosphonate-based LnMOFs still remains a difficult task. So far, only a few examples of three-dimensional networks have been reported. In these cases, the frameworks are constructed by chains of edge-sharing lanthanide polyhedral connected by phosphonate groups. ${ }^{5}$

Recent progress in design of new polyphosphonic ligands has opened the way to the tailor-made synthesis of hybrid inorganicorganic materials. ${ }^{6}$ Diamino tetraphosphonic acids are versatile organic linkers because they may contain diverse functionalities in between the peripheral phosphonate groups and hence new compounds with chemical and structural peculiarities may be prepared. In fact, a number of diamino tetraphosphonates with different alkaline or transition metals showing chain, layered or three-dimensional open framework structures have already been 
reported. $^{7}$ Some of these show interesting luminescent properties, ${ }^{1,5,8}$ excellent selective cation sorption and exchange capacity, ${ }^{9}$ and scale/corrosion inhibition. ${ }^{10}$ Certain metal diamino tetraphosphonates, for example $\mathrm{Ga}^{\mathrm{III}}-\mathrm{H}_{5}$ TDTMP $\left(\mathrm{H}_{8}\right.$ TDTMP $=$ tetramethylenediamine- $N, N, N^{\prime}, N^{\prime}$-tetrakis(methylenephosphonic acid)), have drawn the interest of the medical community because of their ability to suppress metastatic tumours $^{11 \mathrm{a}}$ and others, such as Yb-EDTMP, were used for bone palliation. $^{11 \mathrm{~b}}$

Extending previous work on $\mathrm{CaH}_{6} \mathrm{DTMP}$, an adsorbateresponsive material with $2 \mathrm{D}$ topology exhibiting a "breathing" phenomenon, ${ }^{12}$ herein we report the synthesis and characterization of the flexible multifunctional $\mathrm{La}\left(\mathrm{H}_{5} \mathrm{DTMP}\right) \cdot 7 \mathrm{H}_{2} \mathrm{O}$ $\left[\mathrm{H}_{8} \mathrm{DTMP}=\right.$ hexamethylenediamine- $N, N, N^{\prime}, N^{\prime}$-tetrakis(methylenephosphonic acid)], and its gas adsorption as well as its proton conductivity properties.

\section{Experimental}

\section{Materials}

All starting compounds were from commercial sources and used as received, without further treatment. Deionized (DI) water was used for all syntheses and procedures. $\mathrm{La}_{2} \mathrm{O}_{3}(99.5 \%)$, was from Aldrich, USA and $\mathrm{SmCl}_{2} \cdot 6 \mathrm{H}_{2} \mathrm{O}(99+\%)$ was from Alfa-Aesar, USA. $\mathrm{K}_{6}\left(\mathrm{H}_{2} \mathrm{DTMP}\right)$ (Dequest 2054, $33.5 \%$ stock solution) was from ThermPhos-Dequest, Belgium.

\section{Preparation of lanthanide tetraphosphonate products}

La(H H $_{5}$ TMP) $\cdot 7 \mathbf{H}_{2} \mathrm{O}$ (1). $1 \mathrm{~mL}$ of a $33.5 \%$ stock solution of $\mathrm{K}_{6}\left(\mathrm{H}_{2} \mathrm{DTMP}\right)(0.58 \mathrm{mmol})$ was added to $20 \mathrm{~mL}$ of DI water. The $\mathrm{pH}$ was then adjusted to $\sim 2$ by using consecutively $5 \mathrm{M}$ and $1 \mathrm{M} \mathrm{HCl}$ solutions. Separately, a quantity of $\mathrm{La}_{2} \mathrm{O}_{3}(0.127 \mathrm{~g}$, $0.39 \mathrm{mmol}$ ) was suspended in $30 \mathrm{~mL}$ of DI water and then dissolved by consecutive addition of $5 \mathrm{M}$ and $1 \mathrm{M} \mathrm{HCl}$ solutions, adjusting the $\mathrm{pH}$ to about 0.9 . The two solutions were then mixed and the final $\mathrm{pH}$ was adjusted to 1.2 with a $1 \mathrm{M} \mathrm{NaOH}$ stock solution. The resulting clear colourless solution was left undisturbed for 2 months, after which time a microcrystalline white solid appeared. Alternatively, solid $\mathrm{H}_{8}$ DTMP (Dequest 2051) can be used instead of the $\mathrm{K}_{6}\left(\mathrm{H}_{2} \mathrm{DTMP}\right)$ stock solution. Anal. Calcd (\%) for $\mathrm{LaP}_{4} \mathrm{~N}_{2} \mathrm{O}_{19} \mathrm{C}_{10} \mathrm{H}_{39}$ : $15.92 \% \mathrm{C}, 5.21 \% \mathrm{H}$, $3.71 \% \mathrm{~N}$. Found: $15.07 \% \mathrm{C}, 4.92 \% \mathrm{H}, 3.62 \% \mathrm{~N}$. IR data $/ \mathrm{cm}^{-1}$ : 3429 (br), 3013 (br), 2965 (br), 2779 (w), 2628 (sh), 2366 (w), 2346 (w), 1632 (m), 1482 (m) 1459 (sh), 1438 (m), 1380 (m), 1342 (w), 1297 (m), 1224 (s), 1190 (s), 1162 (s), 1101 (s), 914 (s), $846(\mathrm{w}), 825(\mathrm{w}), 802(\mathrm{w}), 775(\mathrm{~m})$.

$\operatorname{Sm}\left(\mathrm{H}_{5} \mathrm{DTMP}\right) \cdot \mathbf{7} \mathrm{H}_{2} \mathrm{O}$. The same procedure was used as for $\mathrm{La}\left(\mathrm{H}_{5} \mathrm{DTMP}\right) \cdot 7 \mathrm{H}_{2} \mathrm{O}$ (1), except that the metal source was $\mathrm{SmCl}_{2} \cdot 6 \mathrm{H}_{2} \mathrm{O}$ and the final $\mathrm{pH}$ was 0.76 .

By following the same procedure as above for $\mathrm{Ce}\left(\mathrm{NO}_{3}\right)_{3} \cdot 6 \mathrm{H}_{2} \mathrm{O}$, no Ce-containing product was isolated, except halite $(\mathrm{NaCl})$, as confirmed by its powder diffraction pattern.

\section{Crystal structure determination}

Laboratory X-ray powder diffraction (XRPD) patterns were collected on a PANanalytical X'Pert Pro diffractometer in a
Bragg-Brentano reflection configuration by using a Ge(111)

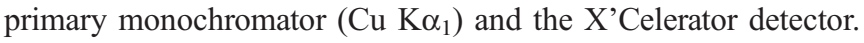
XRPD patterns were auto-indexed using the DICVOL06 $\operatorname{program}^{13}$ and the space groups derived from the observed systematic extinctions were consistent with $P 2_{1} / m$ or $P 2_{1}$.

For the structural determination of $\mathbf{1}$, powder X-ray diffraction data were collected at the high resolution beamline ID31 of the ESRF, European Synchrotron Radiation Facility, (Grenoble, France). A wavelength of $0.2998 \AA$ was selected with a doublecrystal Si (111) monochromator and calibrated with Si NIST ( $a$ $=5.43094 \AA$ ). The Debye-Scherrer configuration was used with the sample loaded in a rotating borosilicate glass capillary of diameter of $1.0 \mathrm{~mm}$. The overall measuring time was $\approx 100 \mathrm{~min}$ in order to have satisfactory statistics over the angular range $1.0-15^{\circ}$ (in $2 \theta$ ). The data from the multi-analyser $\mathrm{Si}(111)$ stage were normalised and summed into $0.003^{\circ}$ step size with local software. Its crystal structure was solved following an $a b$ initio methodology. Initially the centrosymmetric space group $P 21 / m$ was selected for the extraction of the integrated intensities using the Le Bail method ${ }^{14}$ implemented in the GSAS package. ${ }^{15}$ The structure determination was carried out by direct methods using the programs Sir $2006^{16}$ by default setting. The best solution gave the atomic positions for the lanthanum atom, two phosphorus atoms and some oxygen atoms of both phosphonate groups. The missing atoms were localized by difference of Fourier maps. However, not all water molecules could be found in $P 21 / m$. The crystal structure could be satisfactorily completed in the non-centrosymmetric space group $P 2_{1}$ which is in agreement with the hydrogen-phosphonate stoichiometry of $\mathbf{1}$. Furthermore, the fit in space group $P 2_{1}$ was better than in $P 2_{1} / \mathrm{m}$. The structure was optimised by the Rietveld method ${ }^{17}$ using the program GSAS $^{15}$ and the graphic interface EXPGUI. ${ }^{18}$ The following soft constraints were imposed in order to preserve chemically reasonable geometries for the phosphonate, amine groups and alkyl chains: $/ \mathrm{PO}_{3} \mathrm{C}$ tetrahedron $/ \mathrm{P}-\mathrm{O}(1.53(1) \AA), \mathrm{P}-\mathrm{C}(1.80$ (1) $\AA), \mathrm{O} \cdots \mathrm{O}(2.55(2) \AA), \mathrm{O} \cdots \mathrm{C}(2.73(2) \AA), \mathrm{N}\left(\mathrm{CH}_{2}\right)_{3}$ amine group/ $\mathrm{N}-\mathrm{C}(1.50(1) \AA), \mathrm{C} \cdots \mathrm{C}(2.45(2) \AA)$ and/alkyl chain $/ \mathrm{C}-\mathrm{C}$ (1.50(1) $\AA), C_{\text {chain }} \cdots C_{\text {chain }}(2.50(2) \AA)$. Hydrogen atoms were not included in the refinements. The final weight factor for the soft constraints was 20 . Only three isotropic atomic displacement parameters were refined, one for the La atom, a second for the $\mathrm{P}$ atoms and a third one for the rest of the atoms. The crystal structures for the anhydrous, $\mathrm{La}\left(\mathrm{H}_{5} \mathrm{DTMP}\right)$ (2), and rehydrated phases, $\mathrm{La}\left(\mathrm{H}_{5} \mathrm{DTMP}\right) \cdot 2 \mathrm{H}_{2} \mathrm{O}$ (3), were obtained by Rietveld refinement using as starting model the crystal structure of $\mathbf{1}$. The Rietveld plots for $\mathbf{1 - 3}$ are given in the Electronic Supplementary Information (ESI $\dagger$ ) and the relevant crystallographic data are presented in Table 1. Crystal structures have been deposited at CCDC and the reference codes are also given in Table 1.

\section{Thermal analysis}

Differential thermal analysis (DTA) and thermogravimetric analysis (TGA) data were recorded on an SDT-Q600 analyzer from TA instruments. Initially, the temperature was varied from RT to $1273 \mathrm{~K}$ at a heating rate of $10 \mathrm{~K} \mathrm{~min}^{-1}$. Measurements were carried out on a sample in an open platinum crucible under a flow of air. Secondly, a set of measurements were carried out 
Table 1 Crystal data and selected structure refinement parameters for compounds 1-3

\begin{tabular}{|c|c|c|c|}
\hline Compound reference & 1 & 2 & 3 \\
\hline Compound abbreviation & $\mathrm{La}\left(\mathrm{H}_{5} \mathrm{DTMP}\right) \cdot 7 \mathrm{H}_{2} \mathrm{O}$ & $\mathrm{La}\left(\mathrm{H}_{5} \mathrm{DTMP}\right)$ & $\mathrm{La}\left(\mathrm{H}_{5} \mathrm{DTMP}\right) \cdot 2 \mathrm{H}_{2} \mathrm{O}$ \\
\hline Chemical formula & $\mathrm{C}_{10} \mathrm{H}_{39} \mathrm{LaN}_{2} \mathrm{O}_{19} \mathrm{P}_{4}$ & $\mathrm{C}_{10} \mathrm{H}_{25} \mathrm{LaN}_{2} \mathrm{O}_{12} \mathrm{P}_{4}$ & $\mathrm{C}_{10} \mathrm{H}_{29} \mathrm{LaN}_{2} \mathrm{O}_{14} \mathrm{P}_{4}$ \\
\hline Formula Mass & 753.91 & 627.91 & 663.96 \\
\hline Crystal system & Monoclinic & Monoclinic & Monoclinic \\
\hline$a / \AA ̊$ & $13.3444(5)$ & $12.2967(15)$ & $12.5035(6)$ \\
\hline$b / \AA$ & $18.7820(4)$ & $17.7483(21)$ & 18.1874(10) \\
\hline$c / \AA$ & $5.848903(23)$ & $5.9887(8)$ & $5.82000(35)$ \\
\hline$\alpha\left(^{\circ}\right)$ & 90.0 & 90.0 & 90.0 \\
\hline$\beta\left(^{\circ}\right)$ & 97.711(4) & 104.626(6) & 101.923(4) \\
\hline$\gamma\left(\left(^{\circ}\right)\right.$ & 90.0 & 90.0 & 90.0 \\
\hline Unit cell volume $/ \AA^{3}$ & $1452.71(10)$ & $1264.7(4)$ & $1295.95(11)$ \\
\hline$V_{\text {non-H-atom }} / \AA^{3}$ & 20.2 & 21.8 & 20.9 \\
\hline Temperature/K & 293 & 473 & 293 \\
\hline Space group & $P 2_{1}$ & $P 2_{1}$ & $P 2_{1}$ \\
\hline No. of formula units per unit cell, $Z$ & 2 & 2 & 2 \\
\hline No. of independent reflections & 1041 & 1072 & 1098 \\
\hline Data/Restrains/Parameters & $4734 / 68 / 139$ & $4547 / 65 / 105$ & $5134 / 74 / 127$ \\
\hline$R_{\mathrm{WP}}$ & 0.0741 & 0.0812 & 0.0946 \\
\hline$R_{\mathrm{P}}$ & 0.0532 & 0.0604 & 0.0604 \\
\hline$R_{\mathrm{F}}$ & 0.0506 & 0.0504 & 0.0630 \\
\hline CCDC number & 810316 & 810315 & 810317 \\
\hline
\end{tabular}

under $\mathrm{N}_{2}$ flow, saturated with water at $298 \mathrm{~K}$, to characterise the release and uptake of water by $\mathbf{1}$.

On the other hand, a thermodiffractometric study for $\mathbf{1}$ was carried out for the sample loaded in an Anton Paar HTK $1200 \mathrm{~N}$ chamber under static air. Data were collected at 303, 423, 453 and $473 \mathrm{~K}$ with a heating rate of $5 \mathrm{~K} \mathrm{~min}^{-1}$ and a delay time of $10 \mathrm{~min}$ to ensure thermal stabilization. The data acquisition range was $4-80^{\circ}(2 \theta)$ with a step size of $0.008^{\circ}$ and an equivalent counting time of $100 \mathrm{~s} \mathrm{step}^{-1}$.

\section{Textural characterization}

The nitrogen sorption-desorption isotherms were measured in a Micromeritic ASAP 2020 apparatus. The samples were degassed under high vacuum and the isotherms, obtained at $77 \mathrm{~K}$, were analyzed by the Brunauer-Emmett-Teller (BET) method. Carbon dioxide sorption isotherms were measured in a Micromeritic ASAP 2020 apparatus. The samples were degassed at $463 \mathrm{~K}$ for $2 \mathrm{~h}$ and the isotherms obtained at $273 \mathrm{~K}$ were analyzed by the Dubinin-Radushkevich (DR) method. ${ }^{19}$ The adsorption study of NO (at $298 \mathrm{~K}$ ) was carried out following the experimental procedure described elsewhere. ${ }^{20}$ The samples were outgassed at $463 \mathrm{~K}$ under vacuum for $2 \mathrm{~h}$.

\section{Conductivity characterization}

Electrical characterization was carried out on a cylindrical pellet ( $\sim 10 \mathrm{~mm}$ of diameter and $\sim 1 \mathrm{~mm}$ of thickness) obtained by pressing $\sim 0.02 \mathrm{~g}$ of sample at $1000 \mathrm{MPa}$, for $2 \mathrm{~min}$. The pellet was pressed between porous C electrodes (Sigracet, GDL 10 BB, no $\mathrm{Pt}$ ). Impedance spectroscopy data were collected using a HP4284A impedance analyzer over the frequency range from $20 \mathrm{~Hz}$ to $1 \mathrm{MHz}$ with an applied voltage of $0.2 \mathrm{~V}$. Electrical measurements were taken at 289, 291, 293, 295 and $297 \mathrm{~K}$ under a $5 \% \mathrm{H}_{2}-\mathrm{Ar}$ flow and at $98 \%$ relative humidity over the temperature range. All measurements were electronically controlled by the winDETA package of programs. ${ }^{21}$

\section{Results and discussion}

$\mathrm{La}\left(\mathrm{H}_{5} \mathrm{DTMP}\right) \cdot 7 \mathrm{H}_{2} \mathrm{O}$ (1) was obtained by room temperature crystallization from acidic solutions containing $\mathrm{La}^{3+}$ and $\mathrm{H}_{8}$ DTMP. The latter exists in a zwitterionic form (each phosphonate group is monodeprotonated, the two $\mathrm{N}$ atoms are protonated) in $\mathrm{pH}$ regions $<3$, with a total charge of " -2 ". However, in the presence of metal ions (trivalent, in particular) further phosphonate deprotonation occurs. In this case, one of the four phosphonate groups is fully (doubly) deprotonated, hence the ligand acquires a " -3 " total charge. Thus, the charges $("+3$ " from the lanthanum and " -3 " from the ligand) are balanced, and the final product is a neutral framework. The kinetics of the crystallization process is very slow ( 2 months), however this time can be reduced by using more concentrated solutions of the reagents without extensive compromise in the crystallinity of the final product. A similar synthesis for the Sm derivative was also carried out by following the same synthetic procedure. The samarium derivative was isolated and its powder pattern showed lower crystallinity. However, the habit of the Sm-hybrid pattern is similar to that of 1, which points out the isostructural nature of this compound, see Fig. S4 in the ESI. $\uparrow$

\section{Crystal structure}

Compound 1 crystallizes in a monoclinic unit cell with 36 non$\mathrm{H}$ atoms in the asymmetric part of the unit cell. As shown in Fig. 1, the asymmetric unit contains one crystallographically unique $\mathrm{La}^{3+}$ ion, one $\left[\mathrm{H}_{5} \mathrm{DTMP}\right]^{3-}$ anion, and 7 lattice waters. The ligand can be described as a "zwitter ion", as the $\mathrm{N}$ atoms remain protonated. The $\mathrm{La}^{3+}$ centre is coordinated exclusively by six phosphonate oxygen atoms (Figure 1) from six different 


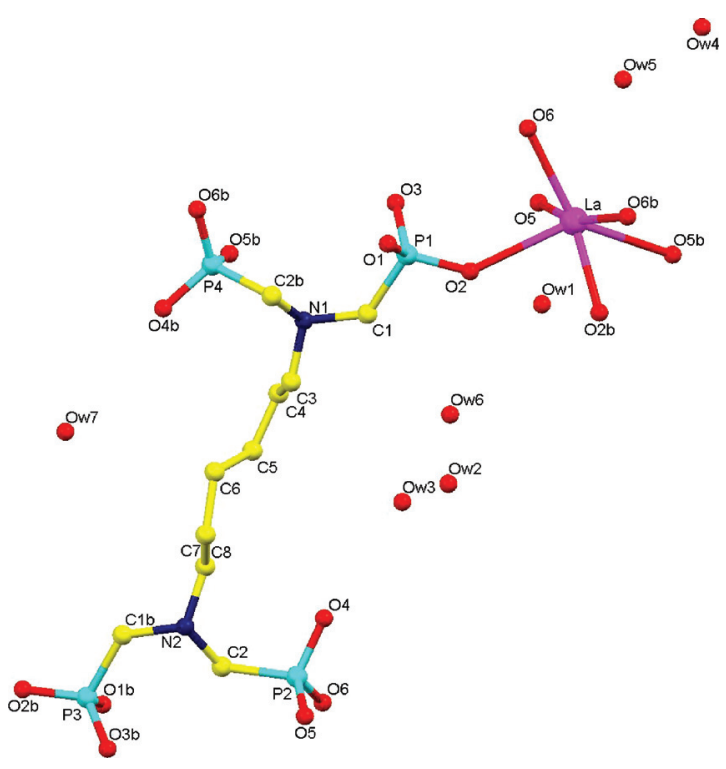

Fig. 1 Structural unit of $\mathrm{La}\left(\mathrm{H}_{5} \mathrm{DTMP}\right) \cdot 7 \mathrm{H}_{2} \mathrm{O}(\mathbf{1})$ with atom labelling.

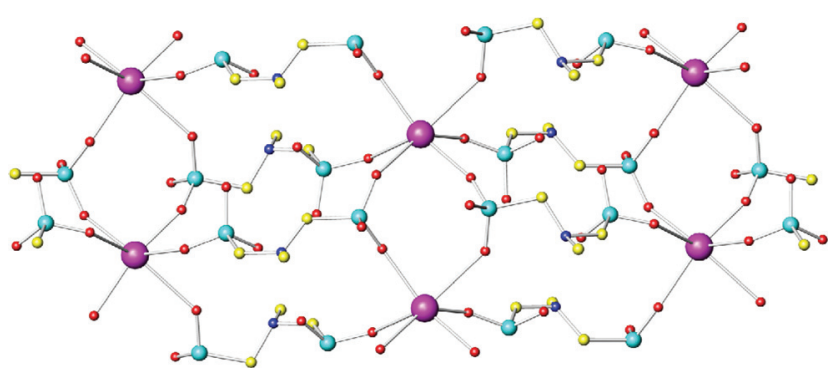

Fig. 2 Ball and stick view of a layer ( $b c$ plane) for $\mathrm{La}\left(\mathrm{H}_{5} \mathrm{DTMP}\right) \cdot 7 \mathrm{H}_{2-}$ $\mathrm{O}$ (1) showing the 8 -membered rings (vertical) and the 16-membered rings (horizontal). Colour codes, La: purple; P: shy-blue; O: red; C: small yellow spheres; N: small blue spheres.

$\left[\mathrm{H}_{5} \mathrm{DTMP}\right]^{3-}$ anions. The La-O distances are in the range 2.28(3)-2.80(3) (Table S1 †).

There are four crystallographically independent phosphorous atoms, with pairs $(\mathrm{P} 1, \mathrm{P} 4)$ and $(\mathrm{P} 2, \mathrm{P} 3)$ located in the opposite extremes of the ligand molecule. $\mathrm{P} 1$ and $\mathrm{P} 3$ are bonded to the $\mathrm{La}^{3+}$ centres through only one oxygen atom, whereas the remaining two phosphonate oxygens are non-coordinating. Higher connectivity is displayed by $\mathrm{P} 2$ and $\mathrm{P} 4$ groups, which bridge two $\mathrm{LaO}_{6}$ polyhedra, through two oxygen atoms. This type of linkage gives rise to infinite chains along the $c$-axis, forming 8 member rings (see Fig. 2). The third phosphonate oxygen atoms of $\mathrm{P} 2$ and $\mathrm{P} 4$ are uncoordinated and point out of the plane. The chains of $\mathrm{LaO}_{6}$ polyhedra, interconnected by bridging phosphonate tetrahedra, build a corrugated layer in the plane $b c$, containing inside 16-membered rings (see Fig. 2). Neighbouring layers are connected by the organic linker, resulting in an open 3D pillared framework, in which the 1-D channels are filled by seven lattice water molecules (see Fig. $3 \mathrm{a}$ and $\mathrm{S} 5 \dagger$ ). Based on the above structural data the precise molecular formula of $\mathrm{La}$ $\left(\mathrm{H}_{5} \mathrm{DTMP}\right) \cdot 7 \mathrm{H}_{2} \mathrm{O}$ (1) can be expressed as $\mathrm{La}\left[\left(\mathrm{O}_{3} \mathrm{PCH}_{2}\right)\right.$ $\left.\left(\mathrm{HO}_{3} \mathrm{PCH}_{2}\right) \mathrm{N}(\mathrm{H})\left(\mathrm{CH}_{2}\right)_{6} \mathrm{~N}(\mathrm{H})\left(\mathrm{CH}_{2} \mathrm{PO}_{3} \mathrm{H}\right)_{2}\right] \cdot 7 \mathrm{H}_{2} \mathrm{O}$. a)
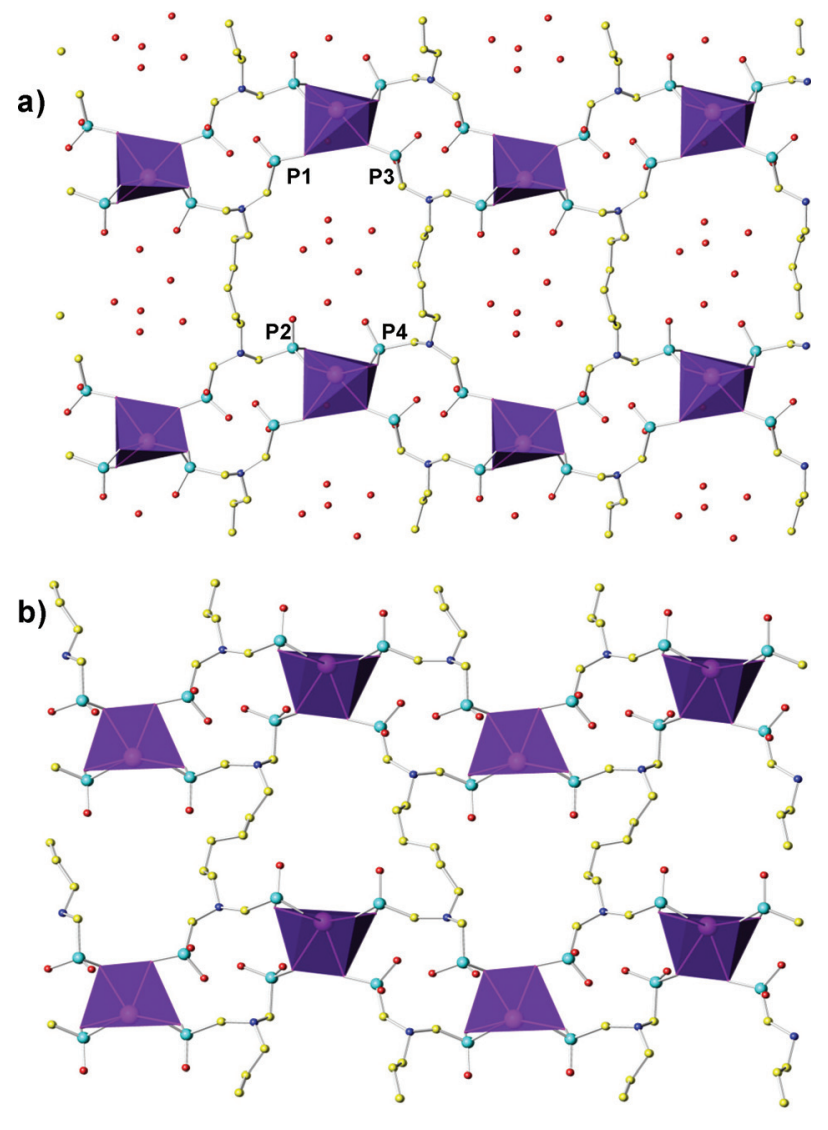

c)

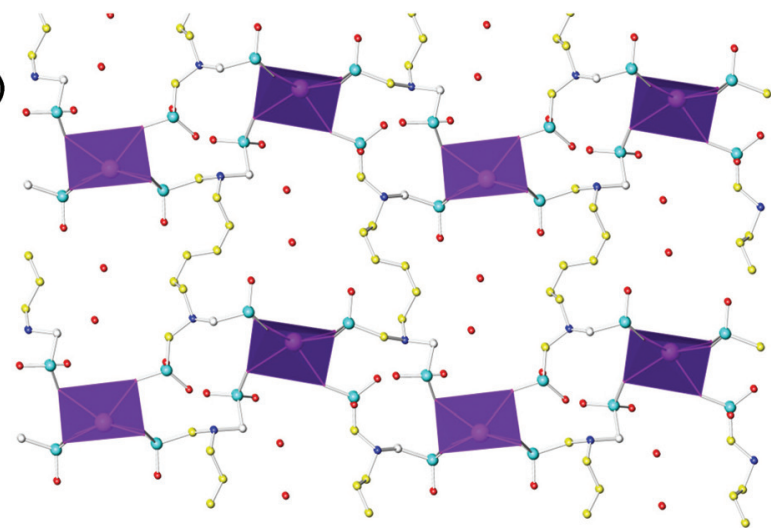

Fig. 3 Crystal structures of the hybrids showing the structural changes during the dehydration/rehydration processes: (a) $\mathrm{La}\left(\mathrm{H}_{5} \mathrm{DTMP}\right) \cdot 7 \mathrm{H}_{2} \mathrm{O}$ (1); (b) $\mathrm{La}\left(\mathrm{H}_{5} \mathrm{DTMP}\right)$ (2); (c) $\mathrm{La}\left(\mathrm{H}_{5} \mathrm{DTMP}\right) \cdot 2 \mathrm{H}_{2} \mathrm{O}$ (3). Selected atoms are labelled.

Five lattice waters are situated close to the centre of the channels interacting to each other by H-bonds (see Fig. S6 and Table $\mathrm{S} 2 \dagger$ ). The two remaining lattice waters, Ow1 and Ow5, are closer to the lanthanum atoms and interacting strongly by $\mathrm{H}$ bond with the oxygen and of two phosphonate groups (see Table S2†).

The way the organic linker is coordinated to $\mathrm{La}^{3+}$ is markedly different from the coordination mode adopted in $\mathrm{Ca}\left(\mathrm{H}_{6} \mathrm{DTMP}\right)$ and $\mathrm{Gd}(\mathrm{III})$-diaminotetraphosphonates, ${ }^{5 \mathrm{~b}}$ despite the fact that ions $\mathrm{La}^{3+}$ and $\mathrm{Ca}^{2+}$ are quite similar in size and possess the same metal : linker ratio in the corresponding derivatives. Thus, for the 


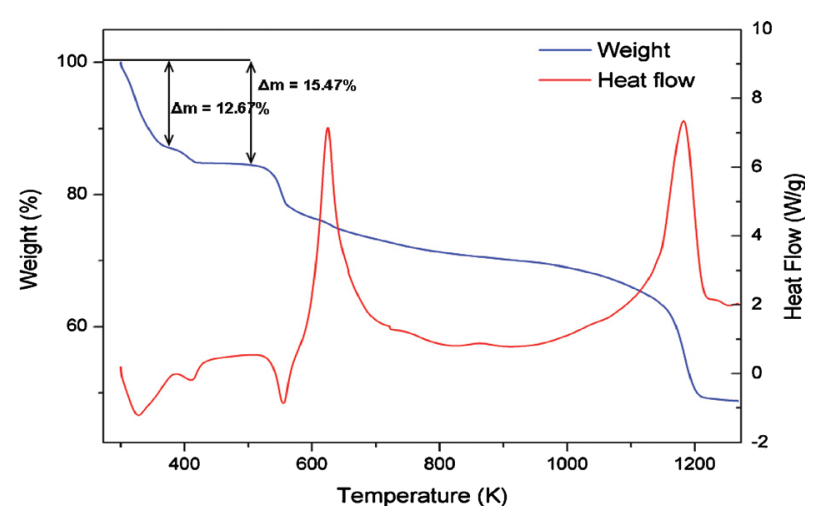

Fig. 4 TGA-DTA curves of $\mathbf{1}$.

layered $\mathrm{Ca}\left(\mathrm{H}_{6} \mathrm{DTMP}\right)$ derivatives, ${ }^{12}$ each amino-bis(methylenephosphonate) moiety coordinates to a $\mathrm{Ca}^{2+}$ centre. Each $\mathrm{H}_{6}$ DTMP ligand bridges two $\mathrm{Ca}^{2+}$ centres giving rise to infinite chains, connected to each other through $\mathrm{Ca}-\mathrm{O}$ bonds stemming from the remaining phosphonate O's. However, in compound $\mathbf{1}$ only phosphonate groups bridge lanthanum polyhedra in infinite chains with 8 -membered rings separating the metal centres (see Fig. 2). These structural features (8-atom and 16-atom rings) are also present in $\mathrm{Zn}\left(\mathrm{H}_{6} \mathrm{DTMP}\right) \cdot \mathrm{H}_{2} \mathrm{O}$ but the resulting framework is different. ${ }^{7 \mathrm{c}}$ Other metal tetramethylene-diamine- $N, N, N^{\prime}, N^{\prime}$-tetrakismethylenephosphonates display pillared frameworks but with different connectivities. ${ }^{22}$

\section{Thermal behaviour}

Coupled TGA-DTA curves for $\mathbf{1}$ are depicted in Fig. 4. The TGA curve shows that complete dehydration proceeds through two stages, leading to a weight loss of $15.5 \%$ (calcd 16.7\%) at $423 \mathrm{~K}$. The first step occurs from RT up to $373 \mathrm{~K}$ and corresponds to the release of five lattice waters (weight loss exp. $12.7 \%$, calcd $11.3 \%$ ). The second step, from 373 to $413 \mathrm{~K}$, corresponds to the loss of two additional water molecules.

The water release pattern measured by TGA is in agreement with the structural study. The first mass loss corresponds to the loss of the five lattice waters located in the centre of the channels. The second mass loss is due to the two water molecules strongly H-bonded to the phosphonate groups. There is a plateau from $\sim 423$ to $\sim 503 \mathrm{~K}$ where no mass loss is observed. For temperatures higher than $523 \mathrm{~K}$, the material decomposes in two steps $(523-673 \mathrm{~K}$ and $673-1223 \mathrm{~K})$. The total observed mass loss of $\sim 51.1 \%$ at $1273 \mathrm{~K}$ corresponds well to the calculated $50.17 \%$ (based on the formation of $\mathrm{La}\left(\mathrm{PO}_{3}\right)_{3}$, which was identified by its powder pattern, PDF \#00-033-0717).

The dehydration process has been followed by thermodiffactometry (see Fig. 5). In agreement with the TGA study, full dehydration takes places at $423 \mathrm{~K}$. Heating at this temperature results in a crystalline dehydrated phase, $\mathrm{La}\left(\mathrm{H}_{5} \mathrm{DTMP}\right)$ (2). The process is only partially reversed after cooling at room temperature and exposing 2 to the air for $1 \mathrm{~h}$. Under these conditions, only two water molecules are incorporated within the framework. This partial rehydration leads to a third crystalline phase, $\mathrm{La}\left(\mathrm{H}_{5^{-}}\right.$ DTMP) $2 \mathrm{H}_{2} \mathrm{O}$ (3) that seems to remain stable at room temperature. 3 was kept at room temperature for 7 days in a closed

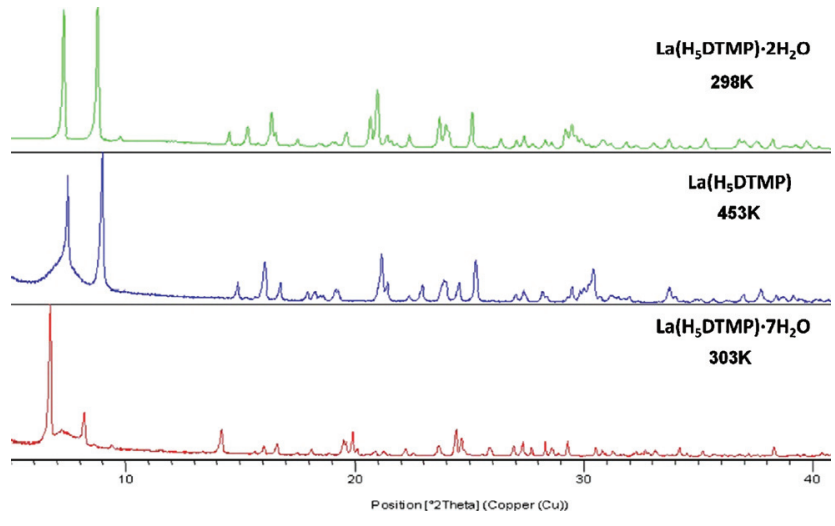

Fig. 5 Selected thermodiffraction data for $\mathrm{La}\left(\mathrm{H}_{5} \mathrm{DTMP}\right) \cdot 7 \mathrm{H}_{2} \mathrm{O}$ (1).

vessel under a humid atmosphere, produced by saturated $\mathrm{NaCl}$, and with the powder pattern of the solid remaining unchanged. Both phases, $\mathbf{2}$ and 3, were autoindexed using the DICVOL06 program in monoclinic unit cells related to the initial cell.

The fundamental topology and dimensionality of the network, characteristic of phase $\mathbf{1}$ remain basically unchanged in phases $\mathbf{2}$ and 3 (Fig. 3b and 3c, respectively). However, the loss of lattice water and further partial rehydration entails changes in the unit cell parameters, with $a$ and $b$ being shrunk upon removing water from the framework (Table 1). The structural changes may be followed by comparing four selected representative distances (see Fig. 3 and Table 2). The removal of water results in several structural changes: (1) Partial shrinkage of the structure occurs, as inferred from lower interlamellar La …La distance. (2) Higher deformation of the inorganic layers, deduced from higher sheet corrugation distances (calculated as the height of the triangle defined by three adjacent lanthanums within a sheet). (3) Changes in the relative positions of the phosphonate groups with respect to the metal centres (P1 ..P 3 and $\mathrm{P} 2 \ldots \mathrm{P} 4$ distances). It is noteworthy to highlight that the "long" P1 ..P3 distance shortens, but, in contrast, the "short" P2...P4 distance lengthens on dehydration. These two distances are quite similar in the anhydrous 2. All these changes are possible due to the partially flexible nature of the $\mathrm{C}_{6} \mathrm{H}_{12}$ chains. The free solvent accessible volume in 2 , derived from PLATON ${ }^{23}$ routine analysis (filling of the cavities with probe spheres of radius $1.2 \AA$ and with hydrogen atoms situated geometrically), was found to be $18.7 \%$. The lattice water molecules in $\mathbf{3}$ are localized in triangular cavities, interacting with oxygen atoms of the phosphonate groups through H-bonds (Fig. 3c, Table S3†).

In order to study the affinity of $\mathrm{LaH}_{5} \mathrm{DTMP}$ for water molecules a thermal analysis with two cycles of heating and cooling

Table 2 Key structural parameters for $\mathrm{La}\left(\mathrm{H}_{5} \mathrm{DTMP}\right) \cdot 7 \mathrm{H}_{2} \mathrm{O}$ $\mathrm{La}\left(\mathrm{H}_{5} \mathrm{DTMP}\right)$ (2) and $\mathrm{La}\left(\mathrm{H}_{5} \mathrm{DTMP}\right) \cdot 2 \mathrm{H}_{2} \mathrm{O}$ (3)

\begin{tabular}{llll}
\hline & $\mathbf{1}$ & $\mathbf{2}$ & $\mathbf{3}$ \\
\hline$(\mathrm{La} \cdots \mathrm{La})_{\text {inter }}(\AA)$ & 15.27 & 12.30 & 12.50 \\
$\mathrm{~h}^{a}(\AA)$ & 4.18 & 5.06 & 4.73 \\
$\mathrm{P} 1 \cdots \mathrm{P} 3(\AA)$ & $6.18(5)$ & $4.58(3)$ & $5.64(3)$ \\
$\mathrm{P} 2 \cdots \mathrm{P} 4(\AA)$ & $4.36(3)$ & $4.61(4)$ & $4.90(3)$ \\
${ }^{a}$ Height for a La $\cdots$ La $\cdots$ La intralayer triangle \\
\hline
\end{tabular}




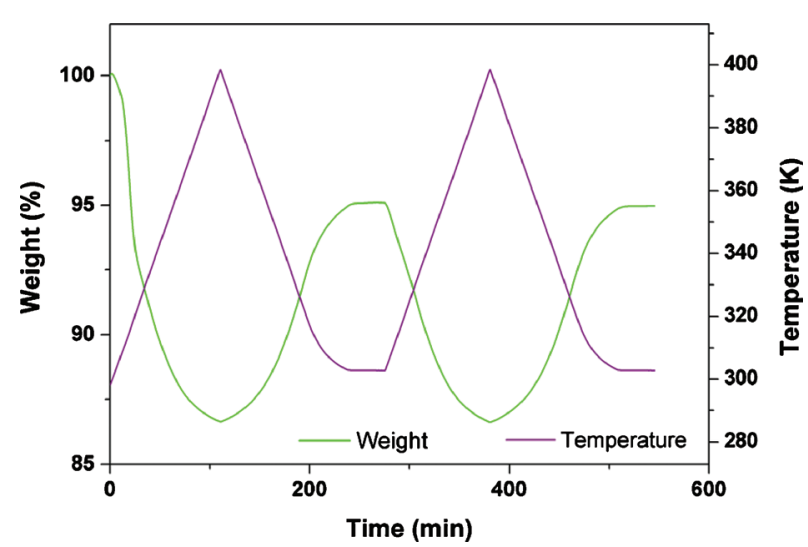

Fig. 6 TGA evolution (green curve) of 1 under a water saturated $\mathrm{N}_{2}$ flow.

(at $1 \mathrm{~K} \mathrm{~min}^{-1}$ up to $403 \mathrm{~K}$ ) was carried out under a $\mathrm{N}_{2}$ flow saturated with water. As shown in Fig. 6, during the heating process the initial weight loss observed is $13.40 \%$ (calcd $13.1 \%$ ) corresponding to removal of 5.5 lattice waters. After cooling, and in the presence of a high relative humidity, a weight gain of $8.43 \%$ is observed. This percentage corresponds to the adsorption of 3.5 lattice waters, an amount that is higher than that observed under normal conditions. Therefore, at the end of this experiment, a stoichiometry close to $\mathrm{La}\left(\mathrm{H}_{5} \mathrm{DTMP}\right) \cdot 5 \mathrm{H}_{2} \mathrm{O}$ is expected. Moreover, the process is completely reproducible after a second cycle. Therefore, all the structural changes occurring during the dehydration/rehydration processes demonstrate that the framework is flexible as it may adopt different configurations as a function of the presence/absence of guest molecules and the environmental conditions.

A further study to confirm the flexibility of the framework upon water exposure was performed at higher temperatures. In this second study, 1 was heated under water saturated $\mathrm{N}_{2}$ flow up to $473 \mathrm{~K}$, which led to the formation of 2 . With cooling under water saturated $\mathrm{N}_{2}$ showed an increase of weight of 10.97 wt \% which is in agreement with the formation of $\mathrm{La}\left(\mathrm{H}_{5} \mathrm{DTMP}\right) \cdot 5 \mathrm{H}_{2} \mathrm{O}$.

\section{Microporosity characterisation}

1 was outgassed under high vacuum at room temperature for $15 \mathrm{~h}$ or at $473 \mathrm{~K}$ for $2 \mathrm{~h}$. Both treatments resulted in the anhydrous material, 2, as determined by the mass losses. On the one hand, the $\mathrm{N}_{2}$ isotherm gave no porosity with specific surface lower than $3 \mathrm{~m}^{2} \mathrm{~g}^{-1}$. On the other hand, the $\mathrm{CO}_{2}$ isotherm (not shown), collected at $273 \mathrm{~K}$ and under pressure up to $1 \mathrm{bar}$, gave a micropore surface area of $84 \mathrm{~m}^{2} \mathrm{~g}^{-1}$, deduced from the Dubinin-Radushkevich ${ }^{19}$ equation, and an adsorption capacity of $0.35 \mathrm{mmol} \mathrm{g}^{-1}$.

We highlight that the isotherm is not saturated at 1 bar and higher pressures would be necessary to access the full pore volume of the structure. This is in agreement with the shape of the 1D channels in $\mathbf{2}$. Higher pressures would allow a gateopening mechanism that may allow a higher gas uptake. A highpressure synchrotron powder diffraction study is planned in order to characterise this flexible framework as a function of the loaded species $\left(\mathrm{CO}_{2}, \mathrm{~N}_{2}\right.$, etc.).

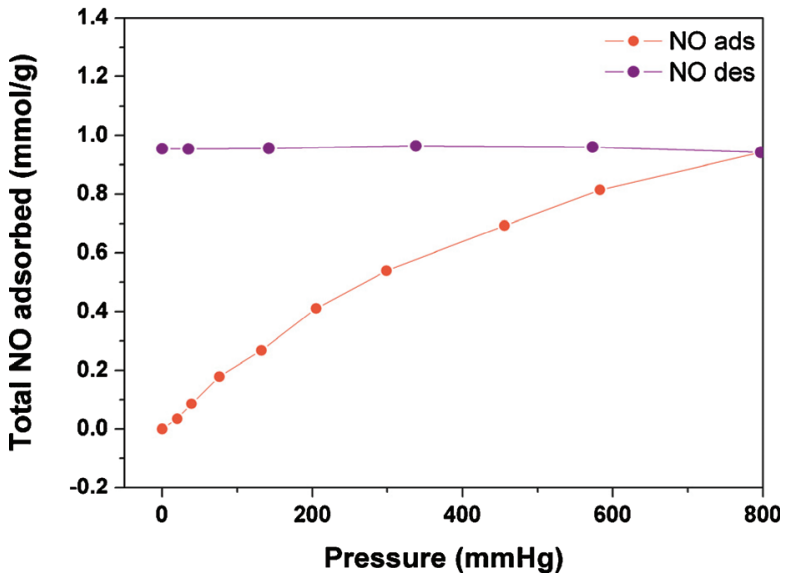

Fig. $7 \mathrm{NO}$ adsorption-desorption measurement for $\mathrm{La}\left(\mathrm{H}_{5} \mathrm{DTMP}\right)$ (2) at $298 \mathrm{~K}$.

Some preliminary studies on NO adsorption have been also carried out for 2. Fig. 7 shows the isotherms for NO adsorptiondesorption at $298 \mathrm{~K}$. The NO adsorption capacity at $\sim 1$ bar was $0.95 \mathrm{mmol} \mathrm{g}^{-1}$ (or $2.85 \mathrm{wt} \%$ ), similar to that found in zeolites ${ }^{24}$ and $\mathrm{Sn}(\mathrm{IV})$ metal diphosphonates. ${ }^{25}$ The hysteresis of the isotherm is significant, indicating a strong irreversible adsorption of NO inside the pores. This irreversible adsorption is likely due to the bonding of the NO molecules to the lanthanum cations.

\section{Proton-conducting characterisation}

A preliminary ionic conductivity study of $\mathbf{1}$ has been carried out as the structural study showed 1D channels filled with water molecules (see Fig. 3 and S6 ${ }^{\dagger}$ ) that may allow proton-conductivity to take place. The impedance study shows that indeed $\mathbf{1}$ exhibits proton conductivity. Fig. 8 shows the real $\left(Z^{\prime}\right)$ and imaginary $\left(Z^{\prime \prime}\right)$ parts of the complex-plane impedance data for 1. Cole-Cole circular arc fitting gave a conductivity $(\sigma)$ of $810^{-3} \mathrm{~S} \mathrm{~cm}^{-1}$ at

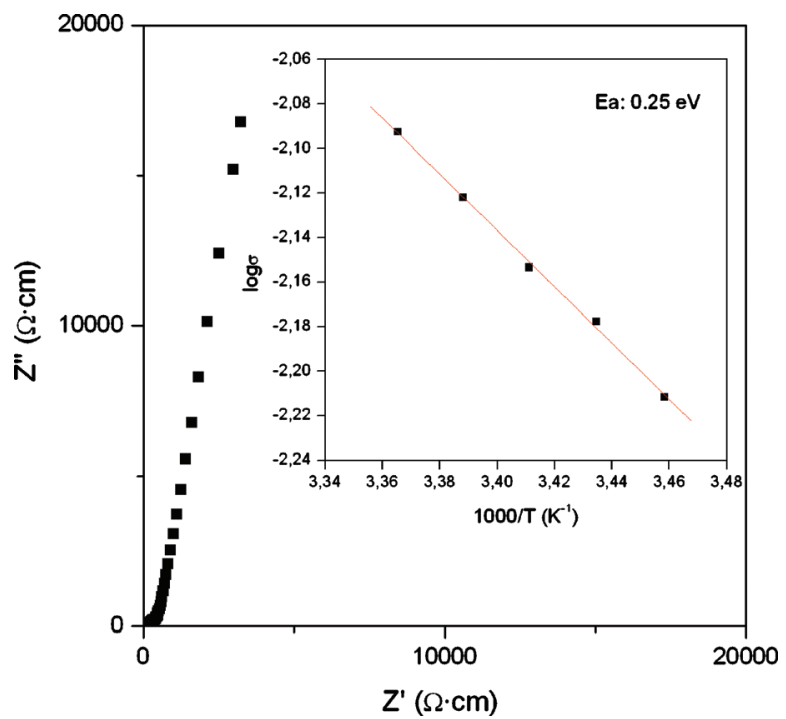

Fig. 8 Complex impedance plane plot for $\mathrm{La}\left(\mathrm{H}_{5} \mathrm{DTMP}\right) \cdot 7 \mathrm{H}_{2} \mathrm{O}$ (1) at $297 \mathrm{~K}$ and $98 \% \mathrm{RH}$. The inset shows the Arrhenius plot over the 289-297 K temperature range in the same conditions. 
$297 \mathrm{~K}$ and $98 \%$ of relative humidity $(\mathrm{RH})$. The temperature dependent study is also given in Fig. 8. Arrhenius plot shows a linear behaviour with an activation energy of $0.25 \mathrm{eV}$. This small number is within the range typically attributed to a Grotthuss transfer mechanism via water molecules, $0.1-0.4 \mathrm{eV}^{26}$ A full proton-conductivity study is out of the scope of this work and it will be reported elsewhere.

The RT obtained value of the proton conductivity is higher than that recently reported for a metal phosphonate MOF material, $\sigma=3.510^{-5} \mathrm{~S} \mathrm{~cm}^{-1}$ at $298 \mathrm{~K}$ and $98 \% \mathrm{RH}^{27}$ The activation energy for the proton transfer process derived from bulk conductivity was $0.17 \mathrm{eV}$. Values of the same magnitude for the proton conductivity, $\sigma=1.110^{-3} \mathrm{~S} \mathrm{~cm}^{-1}$, at room temperature have been very recently reported for a carboxylate$\mathrm{MOF}^{28}$ In this case, the activation energy of the proton conductivity process was nearly the same $0.23 \mathrm{eV}$.

\section{Conclusions}

Two open-framework microporous materials $\mathrm{Ln}\left(\mathrm{H}_{5} \mathrm{DTMP}\right)$ ( $\mathrm{Ln}$ $=\mathrm{La}$ and $\mathrm{Sm}$ ) are reported. The focus in this paper was on the La derivative, which was fully characterized. The as-synthesised compound contains seven lattice waters which may be removed at moderate temperatures while the crystalline metal-organic framework is maintained. The anhydrous material shows high affinity for water but the rehydrate stoichiometries depend upon the experimental conditions. The crystal structures indicate that the lanthanum coordination eenvironment is made-up exclusively by phosphonate oxygens, i.e. none of the water molecules are coordinated to the $\mathrm{La}^{3+}$ centres. This structural feature may have implications in the luminescent properties to be studied. The incorporation of a ligand possessing an aliphatic $-\left(\mathrm{CH}_{2}\right)_{6}-$ chain provides substantial framework flexibility as the structures are adapted to the guest molecule (water) content. The anhydrous material is ultramicroporous and the specific surface for $\mathrm{CO}_{2}$ adsorption (at $273 \mathrm{~K}$ and approximately 1 bar of $\mathrm{CO}_{2}$ ) is $84 \mathrm{~m}^{2}$ $\mathrm{g}^{-1}$. Finally, $\mathbf{1}$ is a proton-conductor with a conductivity of 8 $10^{-3} \mathrm{~S} \mathrm{~cm}^{-1}$ at RT and an activation energy of $0.25 \mathrm{eV}$.

\section{Acknowledgements}

The work at UMA was funded by MAT2010-15175 research grant (MICINN, Spain). The work at the UoC was supported by a grant from the Research Committee of the University of Crete, ELKE, (KA 2573). ESRF is thanked for the provision of synchrotron X-ray beamtime at ID31 beamline.

\section{Notes and references}

1 (a) J. Rocha, L. D. Carlos, F. A. Almeida Paz and D. Ananias, Chem. Soc. Rev., 2011, 40, 926; (b) S. Ma, D. Yuan, X.-S. Wang and H.C. Zhou, Inorg. Chem., 2009, 48, 2072; (c) B. V. Harbuzaru, A. Corma, F. Rey, P. Atienzar, J. L. Jordá, H. García, D. Ananias, L. D. Carlos and J. Rocha, Angew. Chem., Int. Ed., 2008, 47, 1080; (d) B. V. Harbuzaru, A. Corma, F. Rey, J. L. Jordá, D. Ananias, L. D. Carlos and J. Rocha, Angew. Chem., Int. Ed., 2009, 48, 6476; (e) J.-C. Ma, Y.-Y. Liu, J. Yang, Y.-Y. Liu and J.-F. Ma, CrystEngComm, 2011, 13, 3498; $(f)$ P. Silva, F. Vieira, A. C. Gomes, D. Ananias, J. A. Fernandes, S. M. Bruno, R. Soares, A. A. Valente, J. Rocha and F. A. Almeida Paz, J. Am. Chem. Soc., 2011, 133, 15120.
2 (a) L. D. Carlos, R. A. S. Ferreira, V. d. Z. Bermudez and S. J. L. Ribeiro, Adv. Mater, 2008, 20, A1-26; (b) D. T. de Lill and C. L. Cahill, Prog. Inorg. Chem., 2007, 55, 143.

3 (a) B. Cai, P. Yang, J.-W. Dai and J.-Z. Wu, CrystEngComm, 2011, 13, 985; (b) F. Costantino, P. L. Gentili and N. Audebrand, Inorg. Chem. Commun., 2009, 12, 406.

4 (a) J.-G. Mao, Coord. Chem. Rev., 2007, 251, 1493; (b) N. Zhang, Z. Sun, Y. Zhu, J. Zhang, L. Liu, C. Huang, X. Lu, W. Wang and F. Tong, New J. Chem., 2010, 34, 2429; (c) G. Pawlicki and S. Lis, Opt. Mater, 2011, 33, 1544.

5 (a) R.-C. Wang, Y. Zhang, H. Hu, R. R. Frausto and A. Clearfield, Chem. Mater., 1992, 4, 864; (b) S.-M. Ying, X.-R. Zeng, X.-N. Fang, X.-F. Li and D.-S. Liu, Inorg. Chim. Acta, 2006, 359, 1589; (c) S. Bauera, T. Bein and N. Stock, J. Solid State Chem., 2006, 179, 145; (d) J.-M. Rueff, N. Barrier, S. Boudin, V. Dorcet, V. Caignaert, P. Boullay, G. B. Hix and P.-A. Jaffrès, Dalton Trans., 2009, 10614.

6 M. Plabst, L. B. McCusker and T. Bein, J. Am. Chem. Soc., 2009, 131, 18112.

7 (a) F. Costantino, A. Ienco, P. L. Gentili and F. Presciutti, Cryst. Growth Des., 2010, 10, 4831; (b) N. Stock, M. Rauscher and T. Bein, J. Solid State Chem., 2004, 177, 642; (c) K. D. Demadis, C. Mantzaridis, R. G. Raptis and G. Mezei, Inorg. Chem., 2005, 44, 4469; (d) K. D. Demadis, E. Barouda, N. Stavgianoudaki and H. Zhao, Cryst. Growth Des., 2009, 9, 1250; (e) K. D. Demadis, E. Barouda, H. Zhao and R. G. Raptis, Polyhedron, 2009, 28, 3361; $(f)$ K. D. Demadis, S. D. Katarachia, H. Zhao, R. G. Raptis and P. Baran, Cryst. Growth Des., $2006,6,836$.

8 A. Mondry and R. Janicki, Dalton Trans., 2006, 4702.

9 J. Wu, H. Hou, H. Han and Y. Fan, Inorg. Chem., 2007, 46, 7960.

10 (a) K. D. Demadis, E. Barouda, R. G. Raptis and H. Zhao, Inorg. Chem., 2009, 48, 819; (b) K. D. Demadis, C. Mantzaridis and P. Lykoudis, Ind. Eng. Chem. Res., 2006, 45, 7795; (c) E. Akyol, M. Öner, E. Barouda and K. D. Demadis, Cryst. Growth Des., 2009, 9, 5145.

11 (a) M. Su, Y. Qiu and W. Jia, Adv. Ther, 2005, 22, 297; (b) B. Mathew, S. Chakraborty, T. Das, H. D. Sarma, S. Banerjee, G. Samuel, M. Venkatesh and M. R. A. Pillai, Appl. Radiat. Isot., 2004, 60, 635.

12 R. M. P. Colodrero, A. Cabeza, P. Olivera-Pastor, A. Infantes-Molina, E. Barouda, K. D. Demadis and M. A. G. Aranda, Chem.-Eur. J., 2009, 15,6612 .

13 A. Boultif and D. Louer, J. Appl. Crystallogr., 2004, 37, 724.

14 A. Le Bail, H. Duroy and J. L. Fourquet, Mater. Res. Bull., 1988, 23, 447.

15 A. C. Larson and R. B. Von Dreele, "General Structure Analysis System (GSAS)", Los Alamos National Laboratory Report LAUR 86-748 (2004)

16 M. C. Burla, R. Caliandro, M. Camalli, B. Carrozzini, G. L. Cascarano, C. De Caro, C. Giacovazzo, G. Polidori, D. Siliqi and R. Spagna, J. Appl. Crystallogr., 2007, 40, 609.

17 H. M. Rietveld, J. Appl. Crystallogr., 1969, 2, 65-71.

18 B. H. Toby, J. Appl. Crystallogr., 2001, 34, 210.

19 M. Dubinin and L. V. Radushkevich, Proc. Acad. Sci. USSR, 1947, 55, 331

20 B. Xiao, P. S. Wheatley, X. Zhao, A. J. Fletcher, S. Fox, A. G. Rossi, I. L. Regli, K. M. Thomas and R. E. Morris, J. Am. Chem. Soc., 2007, 129, 1203.

21 winDETA, Novocontrol GmbH, Hundsangen, Germany, 1995

22 (a) N. Stock, A. Stoll and T. Bein, Microporous Mesoporous Mater, 2004, 69, 65; (b) N. Stock, M. Rauscher and T. Bein, J. Solid State Chem., 2004, 177, 642; (c) N. Stock and T. Bein, Angew. Chem., Int. Ed., 2004, 43, 749.

23 A. L. Spek, Acta. Crystallogr., Sect. D, 2009, 65, 148.

24 P. S. Wheatley, A. R. Butler, M. S. Crane, A. G. Rossi, I. L. Megson and R. E. Morris, J. Am. Chem. Soc., 2006, 128, 502.

25 M. M. Gomez-Alcantara, A. Cabeza, P. Olivera-Pastor, F. FernandezMoreno, I. Sobrados, J. Sanz, R. E. Morris, A. Clearfield and M. A. G. Aranda, Dalton Trans., 2007, 2394.

26 P. Colomban, Proton Conductors: Solids, Membranes and Gels Materials and Devices, Chemistry of Solid State Materials, Vol. 2; Cambridge University Press, Cambridge, U.K., 1992.

27 J. M. Taylor, R. K. Mah, I. L. Moudrakovski, C. I. Ratcliffe, R. Vaidhyanathan and G. K. H. Shimizu, J. Am. Chem. Soc., 2010, 132, 14055.

28 E. Pardo, C. Train, G. Gontard, K. Boubekeur, O. Fabelo, H. Liu, B. Dkhil, F. Lloret, K. Nakagawa, H. Tokoro, S. Ohkoshi and M. Verdaguer, J. Am. Chem. Soc., 2011, 133, 15328. 
